\title{
University News/Nouvelles des universités
}

\section{New Brunswick}

\section{Quiring Receives Merit Award}

Dr. Dan Quiring of UNB's Faculty of Forestry is the recipient of a 1990 University Merit Award.

The UNB Merit Awards recognize outstanding contributions by faculty members in teaching, research and university service. Valued at $\$ 3,200$ each, the awards are made annually on the basis of recommendations from faculty deans, school directors, the director of libraries, and the director of extension and summer session.

Dr. Quiring attracts strong industrial, provincial and federal support for his entomological research, while maintaining an active publication rate and a high level of university service. He has represented his faculty with distinction in a number of local research and technology transfer functions. His reputation as an outstanding instructor at both the undergraduate and graduate levels is attracting students from outside his faculty.

\section{Forestry Professors on IUFRO Program}

Presenting papers at the XIX IUFRO World Congress in Montreal this month (August) are the following UNB forestry professors:

T.C. Bjerkelund ("Closer ties with IUFRO can enhance forest operations research and developments in eastern North America")

E.W. Robak ("OR in forest operations: new environments, tools and approaches")

R.A. Savidge ("Phytohormone regulation of secondary xylem development")

E.K. Morgenstern ("Correlations of traits in tamarack [ Larix laricinal]"')

\section{Student Prize Winners}

At UNB's 161st Encaenia in May, 23 students graduated from the Bachelor of Science in Forestry program and six received Bachelor of Science in Forest Engineering degrees.

Following is the prize list:

Lieutenant-Governor's Silver Medal: Brian Reid, Millville, NB

Canadian Institute of Forestry Merit Award: Rod Cumberland, Mayfield, NB

City of Fredericton Gold Medal: Randy Poole, Conception Harbour, NF

G.D. Estey Memorial Prize: Joseph Kavanaugh, St. Francis Harbour, NS

Videto-Hadley Memorial Prize: Rod Cumberland, Mayfield, NB

Faculty of Forestry Senior Project Award: Denise Hart, Cayuga, ON

Lucien J. Forcier Prize in Silviculture: Todd Burgess, Truro, NS

\section{CIF Gold Medal Recipient}

Roderick E. Cumberland, Mayfield, NB, is the University of New Brunswick's CIF Gold Medal winner for 1990 .

Mr. Cumberland obtained his bachelor's degree at UNB's 161st Encaenia in May. During his time at UNB, he successfully satisfied the award's two main criteria - partici- pation in faculty activities and above-average academic achievement. His extra-curricular activities included being: captain of the UNB Woodsmen's Team for three years; president of the forestry association (1989-90): organizer of a novice chainsaw course for students (1987-90); and proctor of the UNB Neville House residence (1988-90). He attained a cumulative grade-point average of 3.0 and a final term grade-point score of 3.5 .

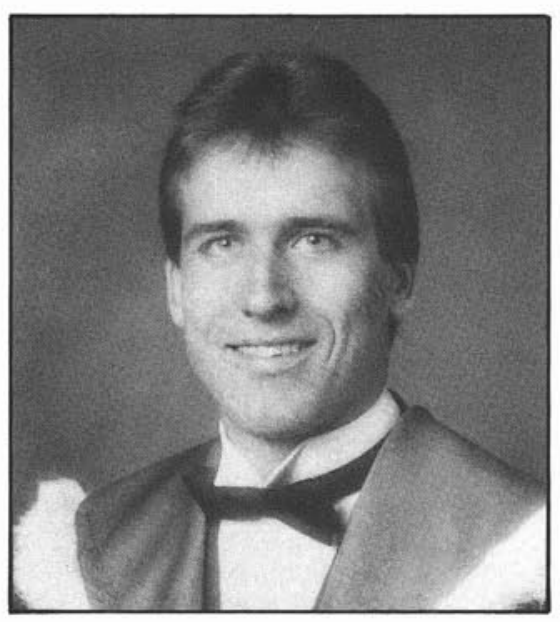

Rod Cumberland

\section{Prizes Awarded}

The J. Miles Gibson Award Committee decided in May to make two awards of $\$ 1100$ each for the coming year. The recipients were: Leslie A. Mahon, Halifax, N.S., and Christine P. Wellings, Brookfield, N.S. Each had a grade-point average of 3.8 .

Also in May, the Faculty of Forestry Undergraduate Scholarships Committee met to select the winner of the $\$ 1500$ B.W. Flieger Memorial Prize for 1990-91.

After reviewing the top candidates entering year three, the committee selected Michelle A. McLaughlin, Fredericton, N.B., who had a grade-point average of 3.89 .

\section{Resignation}

Dr. S.E. Clements, assistant professor of forestry involved in teaching and research in forest management and economics for the past three years, said "Goodbye" to the Faculty in June. He was a popular and effective staff member who will be difficult to replace. He has joined his wife in Oregon.

\section{Retirements}

Professors L.P. Sebastian, wood science, and A.L. VanSlyke, growth and yield, as well as assistant dean and acting chairman of the Forest Resources Department, retired in June after some 30 years of dedicated service. Both had earned substantial reputations in their respective fields and will be sorely missed.

\section{New Chairman}

The new Forest Resources chairman, succeeding acting chairman A.L. VanSlyke, is A. Dickson. Dr. Dickson will be doing double duty as both chairman of Forest Resources and Coordinator of Continuing Education in Forestry.

\section{Faculty Briefs}

Assistant Dean D.A. Daugharty chaired the annual meeting of the National Research Council's Associate Committee on Hydrology in Toronto in June. In the same month and at the same location, he chaired a workshop/meeting on the "Evaluation of Research Needs in Canadian Hydrology". This event was sponsored by the NRC Associate Committee on Hydrology.

Dr. I. Smith, Director of the Wood Science and Technology Centre, was in Beijing, China, in June. While there, he presented papers at two universities and at an international conference on Vibration Problems in Engineering. His papers were entitled: "Finite Element Analysis of Mechanical Timber Joints," "UNB Wood Science and Technology Centre," "Bending Properties of Lumber from Fast-Grown White Spruce," and "In-Situ Non-Destructive Evaluation of Wood Members by Transverse Vibration.'

On August 10 and 13, he travelled to Santiago and Concepcion, Chile, to participate in seminars on timber construction sponsored by the International Development Research Centre, Ottawa.

When the public consultation process, organized by the federal Department of the Environment to discuss its proposed "Green Plan", reached Fredericton recently, forestry faculty members G.A. Jordan, A.L. VanSlyke, E.J. Rickards, R.B.B. Dickson and D.A. Daugharty participated in the sessions conducted.

\section{Continuing Education}

Planning for the fall (1990) and winter (1991) is now under way and the following courses are being considered:

1. Public Relations and Natural Resource Management (Dec. 11-13)

2. Forestland Appraisal (Jan. 13-18)

3. The Illustrated Oral Presentation (Jan. 22-24)

4. Facing the Media (Feb. 15)

5. Deer and Deer Winter Habitat (Feb. 21)

6. Forest Law (Feb. 25-26)

7. Financial Information Management in Forestry (Mar. 5)

8. The Forest Under Stress from Acid Rain and Global Warming (Mar. 12)

9. Ergonomic Applications in Forestry (Apr. 9-10)

10. Identification of Shrubs and Ground Vegetation Important to Forestry in New Brunswick (June 5-6)

Flyers on the above courses with details of cost and instructional content are available on request from the Coordinator, Continuing Education in Forestry, UNB. 


\section{Forestry Focus}

The Summer 1990 issue of the UNB Forestry Focus (Vol. 15, No. 3) is now available. It contains an annotated list of graduate theses and selected undergraduate reports produced within the faculty of forestry during the 1989-90 academic year. These theses and reports may be borrowed. To obtain this issue of the Focus, contact: Coordinator, Continuing Education in Forestry, University of New Brunswick, Bag Service \#44555, Fredericton, N.B. E3B 6C2 (506) 453-4501.

\section{Alex Dickson Coordinator Continuiting Education} in Forestry

\section{Moncton}

\section{L’Université de Moncton bénéficiera d'une forêt expérimentale}

L'Université de Moncton, le ministère provincial des Ressources naturelles et de l'Énergie et la compagnie Fraser ont signé conjointement, le 10 mai 1990, une entente qui permet à l'École de sciences forestières d'avoir accès à un terrain forestier pour y aménager une forêt expérimentale.

L'entente a été ratifiée par le recteur de I'Université de Moncton, Louis-Philippe Blanchard, le ministre des Ressources naturelles et de l'Énergie, Morris Green, et Jeff Leach, v.p. forêts à la compagnie Fraser.

Le territoire est situé à une quarantaine de kilomètres du campus d'Edmundston sur les terres de la Couronne de RestigoucheTobique délivré à Fraser Inc. et s'étend sur une superficie de 830 hectares. La forêt expérimentale a pour premier objectif de servir de laboratoire pour l'enseignement et la recherche. Elle sera aussi utilisée pour la démonstration de diverses techniques d'aménagement forestier et pour la récréation.

\section{Laval}

Faculté de foresterie et de géomatique

Département des sciences forestières et Département de science du bois

\section{Coopération internationale}

\section{Stage au Maroc}

Un groupe de 19 étudiants et étudiantes du cours: "Stage en foresterie internationale" vient de passer une semaine au Maroc. Le but de ces visites est de sensibiliser les étudiants en Aménagement des ressources forestières aux problèmes auxquels les pays en voie de développement sont confrontés dans le domaine de la foresterie, et favoriser l'établissement de liens de coopération avec leurs homologues du pays visité. Elles leur permettent aussi de mieux comprendre le processus de développement international et les encouragent à y participer activement.

\section{Semaine des sciences forestières}

Du 23 au 30 mars se tenait la "Semaine des sciences forestières". Les étudiants de la Faculté ont organisé, à cette occasion, des kiosques d'information au centre commercia de Place Laurier. De plus, une journée colloque dont les thèmes étaient "Les forêts feuillues... un potential à connaître" et "Les contrats d'aménagement et d'approvisionnement forestier" a eu lieu à la Faculté de foresterie et de géomatique. Monsieur Albert Côté, le Ministre délégué aux Forêts y a présenté une allocution.

\section{Colloque sur le dépérissement des érablières}

Le colloque se tiendra du 14 au 17 mai 1990. Trois jours de conférences et une excursion sur le terrain sont prévus. Les grands thèmes abordés seront les stress

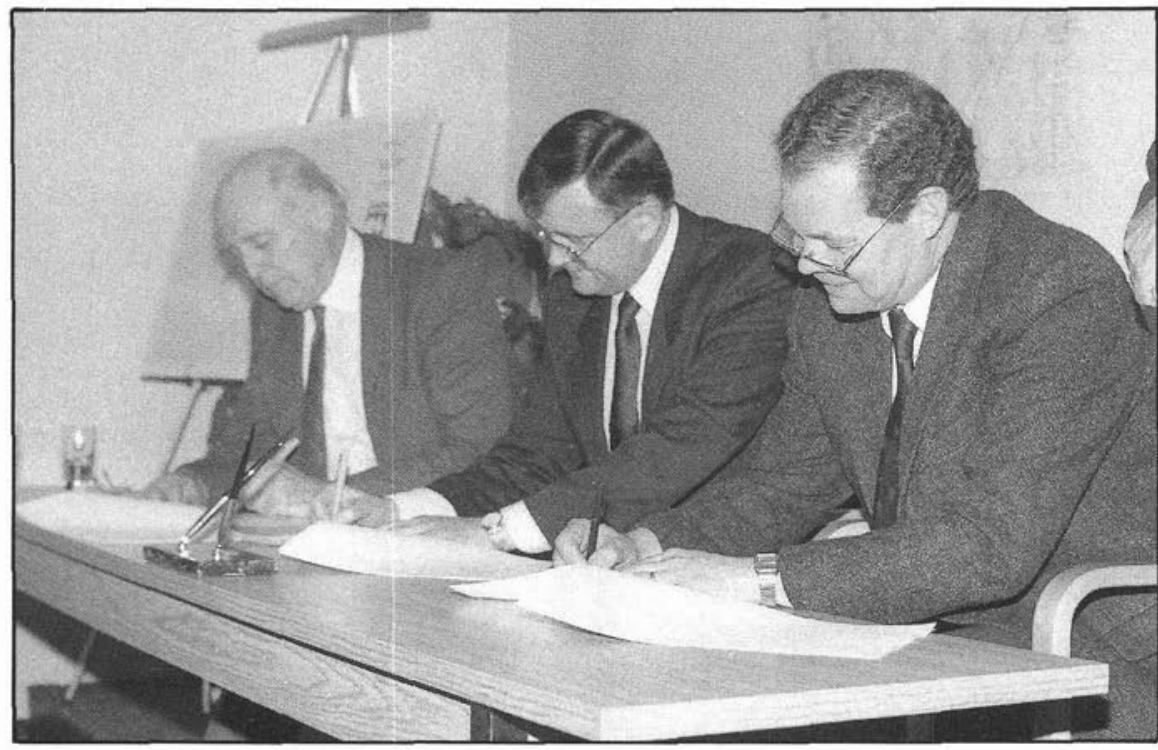

Signature de l'entente portant sur l'aménagement de la forêt expérimentale de l'Université de Moncton. De gauche à droite: Louis-Philippe Blanchard, recteur de l'Université de Moncton Morris Green, ministre des Ressources naturelles et de l'Énergie du Nouveau-Brunswick; Jeff Leach, v.p. forêts à la compagnie Fraser. affectant l'érablière (conditions climatiques extrêmes, épidémies d'insectes, polluant atmosphériques, etc.), les systèmes racinaires, la physiologie, la nutrition et la fertilisation des érablières dépérissantes. En plus des Québécois, des conférenciers de I'Ontario, de la France, de la Belgique, de l'Autriche et de l'Allemagne feront des présentations à ce colloque.

\section{Faculté en Bref}

\section{Corps Professoral}

Le Conseil de l'Université a nommé récemment Yves Piché comme professeur agrégé du Département des sciences forestières. Eric Bauche, B.Sc.A. (génie forestier) M.Sc. $\mathrm{Ph}$.D. (Syracuse) est un nouveau professeur engagé à la Faculté et son champ d'enseignement et de recherche sera l'entomologue forestière.

\section{Entente avec le Ministère de l'environnement du Québec}

Une entente entre l'Université Laval et le Ministère de l'Environnement du Québec a été signée, fin 1989, pour établir à la Faculté un laboratoire de cytologie environnementale et des ressources phytogénétiques. Les objectifs de ce laboratoire sont d'effectue des recherches sur les caractères génétiques des espèces indigènes du Québec, en particulier des plantes menacées ou vulnérables. Un index des nombres chromosomiques des espèces québécoises sera établi et des études sont en cours sur des indicateurs biologiques.

\section{“'Boreal Forest Study'}

Jean Stein, André P. Plamondon, Hank Margolis et Geoffrey Edwards ont participé à un atelier de travail du "Boreal Forest Study" sur invitation de la Société royale du Canada. Cette étude est un programme coopératif de recherche de terrain et d'analyse qui inclut des éléments de la climatologie de la surface terrestre, de la chimie atmosphérique et de l'écologie terrestre. Le but de l'étude est d'étudier les interactions entre le biome de la forêt boréale et l'atmosphère, de façon à clarifier leur rôle dans les changements climatiques globaux. Cette étude a débuté sous l'égide de la NASA qui en est le promoteur.

\section{Collation des Grades}

La collation des grades de la Faculté a eu lieu le 25 novembre 89, et les diplômes ont èté décernés à 99 hommes et 12 femmes. 77 finissants des 3 programmes de foresterie ont reçu les joncs de l'Institut forestier du Canada. On a aussi remis à $\mathrm{M}$. Jean-Pierre Jetté, étudiant en Aménagement des ressources forestières, la médaille d'or de l'Institut.

\section{Bourses}

Aux 1er Cycles

Bourses Domtar: Pierre Labrecque Sylvain Paquet Claude Ruest Luc Lebel 
Bourse de l'Association canadienne des fabricants de panneaux de particules: Claude-René Gagnon

Prix "Wajax Fire Science and Management Report": Patrice McMurray

Bourses du Conseil de recherche en Sciences naturelles et en génie Bourses de recherche du 1er cycle: Stéphane Dubé et Eric Granger

Aux $2 e$ et $3 e$ Cycles

Bourses Abitibi-Price: Patrick Beauchesne et Stéphane Marchand

Bourses Domtar: Lyse Blanchet

Bourse Rexfor: Donald Blouin

Bourses du Conseil de recherche en Sciences naturelles et en génie Bourses post-doctorales: Armand Séguin Bourses d'études supérieures: Daniel Blouin, Steeve Pépin

\section{Diplomation aux $2 \mathrm{e}$ et $3 \mathrm{e}$ cycles}

\section{Sciences du bois}

Roger Hernandex Pena, (Ph.D.). Influence des composantes secondaires et du contrefil sur les propriétés physicomécaniques de bois tropicaux.

\section{Sciences forestières}

Pierrette Cardinal (M.Sc.). La tolérance à l'aluminium chez le pinus strobus. le rôle de l'association ectomycorhizienne.

Alica Chacalo (M.Sc.). Application d'une méthode d'inventaire des arbres urbains sur quelques tronçons de rue de la municipalité de Miguel Hidalgo à Mexico.

Sylvie Côté (M.Sc.). Caractérisation de la régénération préétablie dans les sapinières boréales en fonction de leur situation écologique.

Bruno D'Été (M.Sc.). Utilisation d'agents moussants en lutte aérienne contre les incendies forestiers au Québec.

N'da N'goran Gbesse (M.Sc.): La déforestation en Côte d'Ivoire: ses rapports avec les systèmes de production.

Gaétan Laberge (M.Sc.): Prédiction à court terme de la fonte printanière en forêt boréale.

Sylvie Laliberté (Ph.D.). Morphologie et ultrastructure de systèmes in vitro de plantes ligneuses.

Pierre Larue (M.Sc.): Le milieu riverain forestier: évaluation de son importance pour la faune en sapinière boréale.

Guy Lessard (M.Sc.): Groupes écologiques d'espèces et leur valeur indicatrice dans la sapinière à bouleaux à papier (secteur Forêt Montmorency).

Aphrodise Mbonyintwali (M.Sc.): L'évaluation écologique des terres dans le cadre de l'aménagement des forêts naturelles de la Crête-Nil du Rwanda.

Gabriel Roy (M.Sc.): Application de la phytosociologie à l'étude de l'évolution et du mécanisme du dépérissement des érablières du sud du Québec).

Laurent Roy (M.Sc.): Méthode pour relier la distribution de la régénération au rendement à maturité des peuplements d'épinette noire (Picea mariana(Mill.) BSP)

Hélène St-Pierre (M.Sc.): Régénération après feu du pin gris (Pinus banksiana Lamb.) et de l'épinette noire (Picea mariana Mill. BSP) dans la forêt boréale, lac Desautels, réserve faunique Ashuapmushuan, Québec.

Marie M. Coyea

\section{Toronto}

\section{Faculty Staff}

Dr. Timothy G. Myles, B.A., EPO Biology (Univ. Colo.), M.S., Entomology (Univ. Hawaii), Ph.D. Entomology (Univ. Ariz), will join the Faculty effective 16 July 1990, as the new Director of Urban Entomology. He will conduct the Faculty research program on integrated control of eastern subterranean termites, previously headed by Dr. J. Kenneth Grace. This project is funded by government agencies, Ontario municipalities, and industry.

Dr. J.S. Maini, Assistant Deputy Minister, Forestry Canada, has been appointed as Adjunct Professor of Forest Policy with the Faculty of Forestry, University of Toronto, effective 1 June 1990. Dr. Maini will assist in the development of forest policy research, with special emphasis on land use planning and sustainable development, and serve on graduate student committees.

Dr. J. Vlcek, Professor, responsible for analytical photogrammetry, digital terrain mapping, and remote sensing, will retire effective 30 June 1990. Professor Vlcek started his career with the University of Toronto in 1954, teaching applied physics. He joined the Department of Civil Engineering in 1964 , and was appointed to the Faculty of Forestry in 1977.

Ms. Jane Young, B.Sc., Biology (York Univ.), M.Sc., Plant Physiology (Guelph Univ.) has been appointed as Tutor in Forest Biology, effective 1 May 1990. Her primary duties will be in the area of undergraduate teaching. Ms. Young is currently completing her Ph.D. degree with the Department of Botany, University of Toronto.

Regrettably, Dr. Steven Johnson from the University of Melbourne, who in early December 1989 had accepted the Faculty's offer of appointment as Assistant Professor in Forest Management, informed the Faculty that he will not be joining the University of Toronto, effective 1 July 1990 . He has instead taken a position based in Japan. The search for a candidate to fill the Forest Management position has been re-initiated.

\section{Forest Entomology}

\section{Teaching Award}

Dr. Sandy Smith, Assistant Professor of Forest Pest Management, received the Forester's Club Award for Teaching Excellence, at the 9TO CIF Ring Ceremony. This award is presented by undergraduate students to the professor who has shown enthusiasm and skill in teaching at the Faculty over the past year. Dr. Smith is responsible for the third year core course in forest entomology and the fourth year elective course in forest pest management. Together with Dean Carrow, she also takes part in teaching the graduate course Advanced Topics in Forest Entomology.

\section{Postdoctoral Fellows}

Two postdoctoral fellows have recently joined Dr. Sandy Smith's laboratory to work on forest pest management. Both scientists are directly involved with studies to assess the potential for using the egg parasite, Trichogramma, for biological control of forest insect pests

Dr. Erik Forsse, Research Scientist from the Swedish University of Agricultural Research, Uppsala, Sweden, is expanding current information on flight and dispersal of Trichogramma to improve its efficiency in releases against spruce and jack pine budworms. Dr. Forsse's research in Sweden included the flight behaviour and migration of spruce bark beetles.

Dr. Rob Bourchier, who recently completed his Ph.D. at the University of Waterloo on parasitism and biological control of the gypsy moth, now works with Dr. Smith on the translation of strategy and technology for release of Trichogramma against the spruce budworm to the spruce budmoth. Although the spruce budmoth is a serious pest of young white spruce plantations in New Brunswick and the Gaspe area of Quebec, there is currently no known control available that is considered environmentally acceptable.

\section{Research Support}

Two Master's projects currently underway include a study by Mr. Barry Davidson 8T9 to determine the impact of white pine weevil on jack pine plantations in the Gogama area. This research is supported by E.B. Eddy Forest Products Limited and the Ministry of Natural Resources. Mr. Davidson's study suggests that loss of terminals in jack pine leads to a lowergrade in sawlogs used for timber. Additional work is being carried out to predict damage from white pine weevil on stands under different management regimes; planted, seeded, and seeded and thinned.

Mr. James Brandt $8 T 7$ has received funding from Somerville Nurseries, the Ministry of the Environment, and the University Research Incentive Fund, to determine the life history of the strawberry root weevil

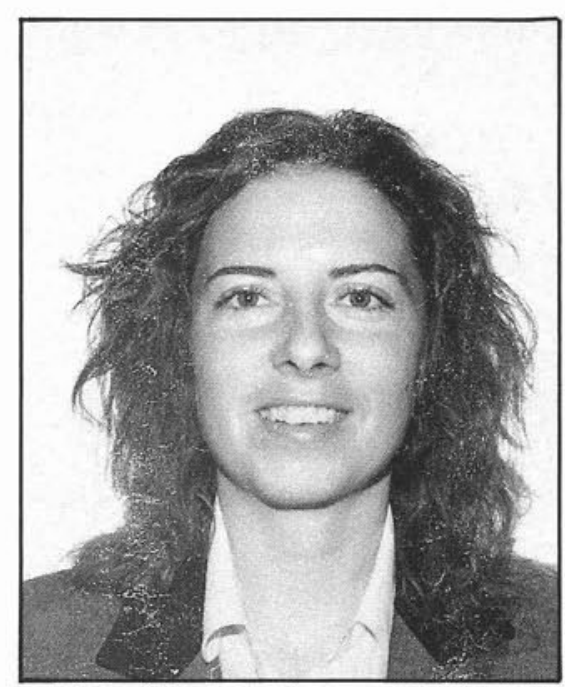

Dr. Sandy Smith 
attacking ornamental conifers and to develop a cost-effective sampling procedure for this pest. Mr. Brandt's work with Somerville Nurseries also includes the investigation of the potential for using entomophagous nematodes for biological control of the root weevil.

\section{Forest Pathology}

\section{Research Paper Award}

Dr. Martin Hubbes and Ms. Dolly Lin, together with Dr. Harry Powers of the USDA Forest Service, received the Outstanding Research Paper Award at the Southwide Forest Disease Workshop in January, 1990, for their paper entitled "Interspecific and intraspecific differentiation within the genus Cronartium by isozyme and protein pattern analysis". The Outstanding Paper Award is presented for a paper published within the 18 months since the previous meeting. Membership of the Southwide Disease Workshop includes forest pathologists from universities, industries, and governments; tree geneticists; physiologists; and others working in areas related to forest diseases.

\section{IUFRO World Congress}

Dr. Martin Hubbes, has accepted an invitation by IUFRO, Division 2, to speak at the subplenary session "Contributions of Biotechnology to Forest Research", on August 9th. Dr. Hubbes' topic will be "Engineering pest resistance in trees".

\section{Graduate Department of Forestry}

The Department conferred $13 \mathrm{MScF}$ and two Ph.D. degrees in the spring of 1989 . Currently registered with the Department are 57 students: Ph.D. 21, MScF 32, MScF/ES 2, and Special 2. Countries of origin of registered graduate are: Canada 30 , China 11, Kenya 5, India 3, United States 2, Korea 2, Finland 1, Greece 1, Somolia 1, and Philippines 1. A large number of applications have been received for graduate studies for $1990 / 91$. Of these, $49 \mathrm{MScF}$ and $41 \mathrm{Ph}$.D. applications are being processed. So far, offers have been sent to and accepted by $23 \mathrm{MScF}$ and 9 Ph.D. students.

\section{Undergraduate Department of Forestry}

In May 1990, first year students completed FOR114 Forest Measurement Techniques, at the Petawawa National Forestry Institute, Chalk River. Students were introduced to cruising and sampling methods for forest inventory purposes. Academic staff included Professor V.G. Smith and Ms. Jane Young, as well as technicians J.A. McCarron and I.D. Kennedy. The Faculty would like to express its appreciation to PNFI staff for their involvement in a segment of course exercises this year.

\section{Award Winners 1990}

Bachelor of Science in Forestry (B.Sc.F.)

McDonell CP - Canadian Institute of Forestry Medal

Henry CP - Ontario Professional Foresters Association Prize

Third Year

Cserey B - Edward Elsworth Johnson Undergraduate Forestry Scholarship
Sommerville DC - F.K. Morrow Forestry Scholarship

Dunlop AJ - John A. Gillies Scholarship

Cserey B/Dunlop AJ - T.W. Dwight Prize in Mensuration

\section{Second Year}

MacLellan JI - Edward Elsworth Johnson Undergraduate Forestry Scholarship

MacLellan JI - Harold S. Edmonds Scholarship

Bauer KM - John A. Gillies Scholarship Mabee WE - Frank A. MacDougall Scholarship

Bauer KM - M.R. Glavicic Prize

\section{First Year}

Simpson MF - Edwards Elsworth Johnson Undergraduate Forestry Scholarship

Lam TP - Wallace A. Delahey Scholarship Simpson MF - John A. Gillies Scholarship Kalmakoff J/Simpson MF — Robert C. Hosie Prize in Dendrology

Simpson MF — Fred G. Jackson Award

Ursula Cattelan 1 June 1990

\section{Alberta}

Dr. Peter J. Murphy has stepped down as Associate Dean of Forestry in the Faculty of Agriculture and Forestry effective July 1 . Pete will be going on a well-deserved administrative leave for the next year.

Back from a year of administrative leave is Dr. Jim Beck, former Chairman of the Department of Forest Science. Jim spent last fall at the University of Berkeley and this year has been spending a lot of time out at Hinton working on plans for incorporating wildlife habitat management on Weldwood's FMA.

Mr. Brian Whittingham, a third-year student, and Mr. Tony Bild, a fourth-year student, placed third in the 1990 Wajax Fire Management Technical Report Competition. Both individuals are students in the Faculty of Agriculture and Forestry, Department of Forest Science at the University of Alberta. Their award winning paper, titled: "Design Plan for the Folding Fire Pump Intake" presents an innovative and cost effective system for quickly setting up a Mark III fire pump. Both students have extensive experienced in forest fire suppression. They used this experience and their engineering course work to perfect their design. Currently, the paper work has been processed to patent this original idea

Dr. Paul Woodard, Professor of Forest Science, recently received $\$ 30,000$ from the Alberta Recreation, Parks and Wildlife Foundation in support of his caribou and elk habitat improvement research. The project, now in its third year, involves a study of lichen regeneration after clearcutting. $\mathrm{Dr}$. Joan Snyder, Grande Prairie Regional College, is the other principal scientist. Support has also been provided by Alberta Fish and Wildlife and Wildlife Habitat Canada. CANFOR, Weldwood, Alberta Newsprint, and Procter and Gamble also contributed in association with the NSERC/Forestry Canada/Industry partnership program.

Ellen Macdonald

\section{UK Foresters' Tour}

On May 21, 1990, six foresters from the United Kingdom, representing the four forestry schools and the UK Forestry Commission, arrived in Edmonton to begin a twoweek forestry tour of Alberta and British Columbia

The group comprised Mr. Philip Adlard, Senior Research Officer at the Oxford Forestry Institute; Mr. T. Calvin Booth, Chief

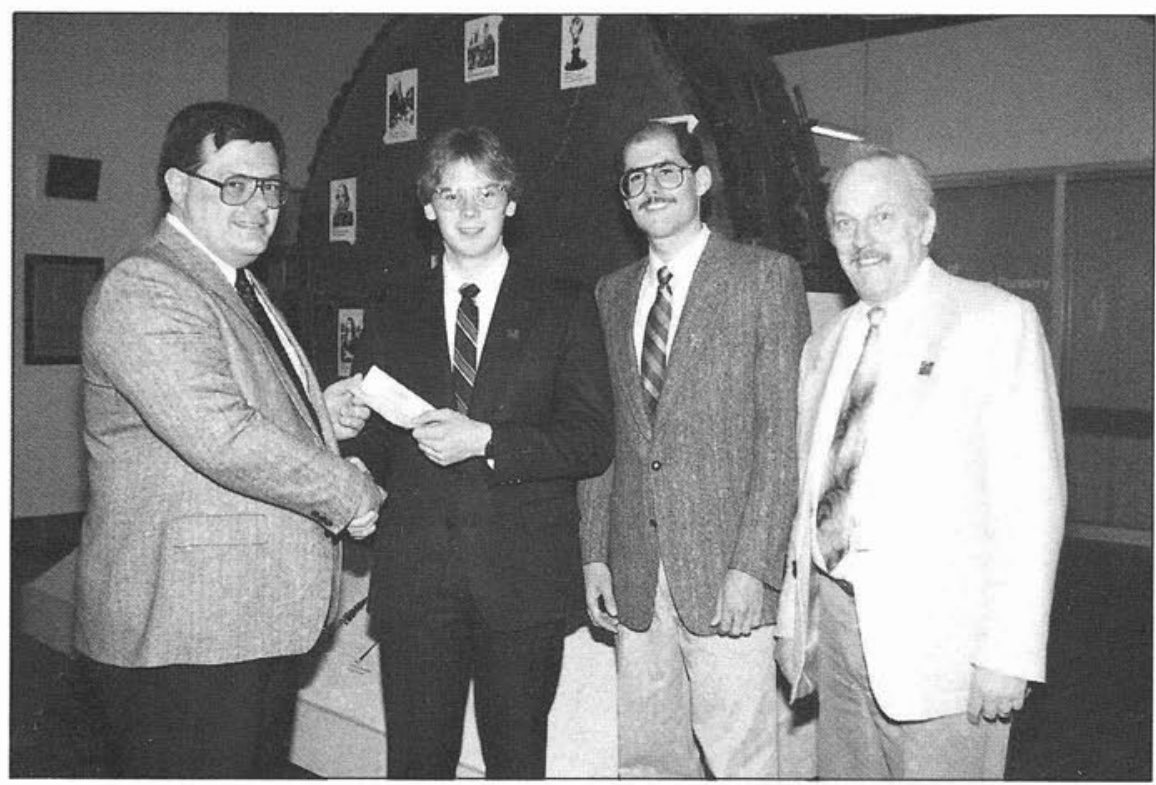

Mr. Brian Whittingham receives the cheque from Mr. Bob Reid, Vice-President (Alberta), Wajax Industries Limited, while Tony Bild, a co-author, and Earl Kayne, Regional Parts Manager, Wajax observe. 


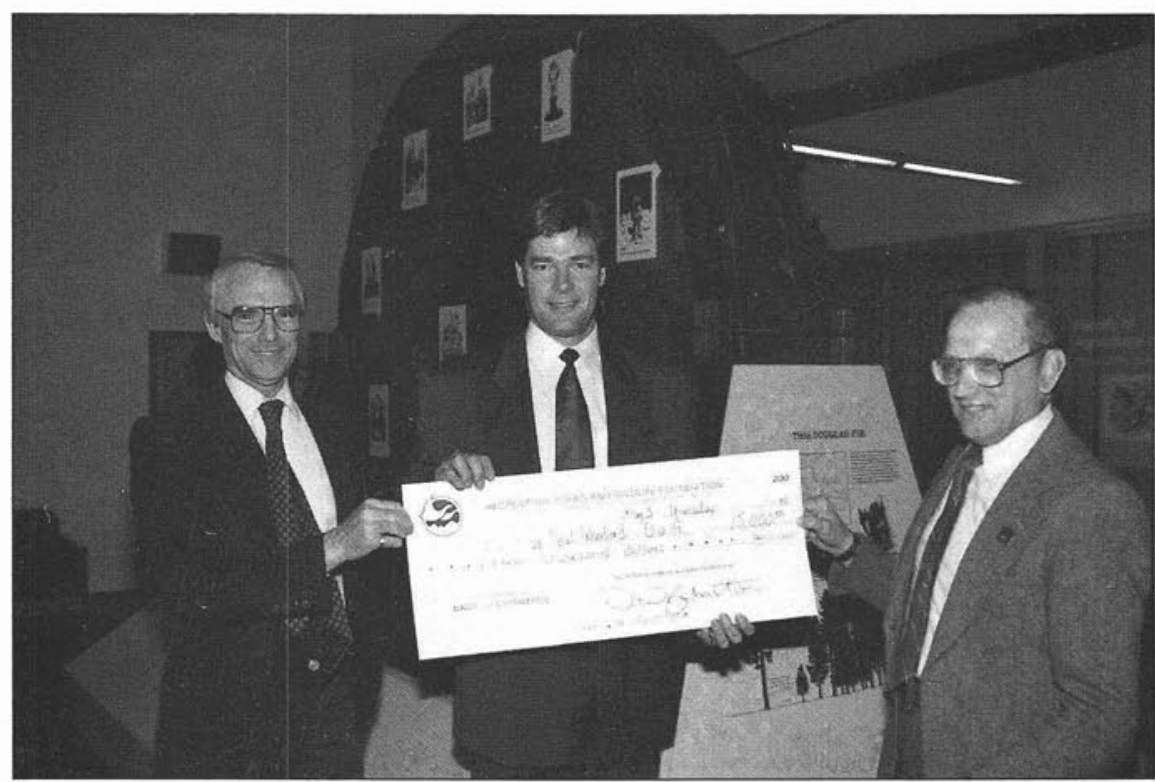

Dr. Peter J. Murphy, Associate Dean-Forestry (left), and Dr. Steve Pawluk, Associate DeanResearch (right) both in the Faculty of Agriculture and Forestry accepting a $\$ 30,000$ cheque from Mr. David Johnston representing the Recreation, Parks and Wildlife Foundation. $\mathrm{Dr}$. Woodard was unable to attend the cheque presentation due to a last minute schedule change related to a range improvement fire.

Research Officer (north) with the Forestry Commission; Dr. John Hetherington, Deputy Head of the School of Agricultural and Forest Sciences of the University of Wales, Bangor; Dr. Douglas Malcolm, Head of the Department of Forestry and Natural Resources of the University of Edinburgh; Professor Hugh Miller, Head of the Department of Forestry at Aberdeen University; and Dr. Howard Wright, deputy Director of the Oxford Forestry Institute. Dr. Peter Murphy planned and organized the tour, which was led by Drs Rich Rothwell, Sally John, and Jean Brouard, with the assistance and support of representatives of the forest industry and government agencies. Mr. Brian Maier of the Alberta Forest Service helped make arrangements in the field.

Beginning with a brief visit to the Department of Forest Science on Tuesday morning, the group then toured the Alberta Research Council facilities. On Wednesday they toured the Alberta Forest Service Pine Ridge nursery, later paying a brief but memorable visit to several very large bison; and on Thursday morning left Edmonton for a tour of west-central Alberta. Millar Western and Blue Ridge Lumber gave them an interesting and comprehensive tour of their woods operations, including harvesting trials and operations, genetic tests, and operational and experimental silvicultural techniques, and also hosted a dinner for the group that evening. On Friday the Alberta Forset Service showed the group the AFS/CFS drainage trials at Wolf Creek, and in the afternoon they toured the Weyerhauser Canada oriented strand board mill. On Saturday morning Mr. Jim Molnar of the AFS explained the Forest Service disking and thinning trials, and also described their program of recreational site development.

Sunday was a day of enthusiastic sightseeing and exploring along the Icefields
Parkway. A brisk stroll up the lower portion of the Columbia glacier was followed by another climb, with the help of a cable car, to admire the glorious view from the summit of the Whistlers. At one point a family of black bears obligingly ambled out of the woods to graze by the highway; elk, mountain sheep, beaver and deer were also much admired. On Monday, after spending the night at the Forest Technology School at Hinton, the group visited Weldwood's operations, where provoking view of the company's nursery, growth and yield, harvesting, recreation and management programs. The Alberta portion of the tour closed with a barbecue dinner at the Black Cat Ranch, hosted by Weldwood.

Sally John

\section{British Columbia}

\section{Faculty News}

Thirty-seven B.S.F. and three B.Sc. degrees were awarded at this year's spring graduation. A further ten to fifteen students will be eligible for fall graduation. Spring gruduating students together with their thesis/essay titles are listed below.

\section{Spring Graduates}

Allen, J.S. Field evaluation of the attractiveness of semiochemicals for the spruce beetle. Dendroctonus rufipennis (Kirby) (Coleoptera: Scolytidae)

Beltz, J. Forest management and overwintering sites of coho salmon (Oncorhynchus kisutch).

Bieber, W. The application of "New Forestry" in British Columbia and a method of requirements.

Biggs, D.T. The natural regeneration of coastal western redcedar. they were given an excellent and thoughtdetermining coarse woody debris
Bodley, P.M. An examination of fish/forestry interactions on coastal streams in British Columbia: Forest practice influences on salmon habitat.

Boyd, B.E. A simulation of a logging maintenance operation.

Brownie, K.J. An analysis of fuelwood shortages and potential solutions: In Sub Saharan Africa.

Chipera, B. A perspective of social forestry: The Indian experience.

Christie, D.A. An economic analysis of two secondary log transport systems in the Surf Inlet.

Clark, I.T. An evaluation of mixedwood harvesting with residual spruce protection in west-central Alberta.

Conville, T.D. Using ecological analysis to quantify coastal Douglas-fir productivity for private land.

Cuthill, M.E. Spacing trials in stagnant lodgepole pine in the Okanagan.

Elden, C. Comparison of conventional and roadside skidder logging in the south Cariboo forest region.

Eso, B. Managing for improved occupational health and safety in the manufacturing industry.

Fraser, S. Snow avalanches and mountain forests in British Columbia.

Friberg, R.F. Changing strategies for forest development in developing countries.

Gage, R.M. The Campbell River Estuary: A report of intertidal marsh islands created for estuarine rehabilitation purposes.

Glover, G.J. Cloning trails of Chamaecyparis nootkatensis.

Goss, G.R. Partial or selective cutting lodgepole pine stands to reduce their susceptibility to mountain pine beetle infestations.

Graham, B. Investigation of the natural regeneration and growth characteristics of western hemlock in coastal British Columbia.

Hardy, R.W. Growth analysis of Engelmann spruce and lodgepole pine, during the 1989 growing season, when planted with GROMAX.

Heyde, B.C. Management of Canada geese in the Fraser valley.

Hopwood, D.G. Shade tolerance of Douglas-fir in the CFDMM/FD-Oregon grape site association: A pilot study.

Horn, D.E. The effect of privatization on British Columbia's provincial parks.

Johnson, A.D. A comparison of line speed and line pull between yarding in coastal B.C.

Loggin, L.T. Value added assessment of forests on private lands.

McDonald, D.A. Sea-to-sky local resource use plan and harvesting within the sea-to-sky corridor.

McGowan, D.L. Public relations and public involvement in the B.C. forest industry: A documentation.

Messenger, M.A. A discussion of social factors influencing the association of British Columbia professional foresters.

Moi, A.W. Overview of the ecology and management of mountain pine beettle infestations.

Moss, J.M. Comparative analysis of forest and agricultural soil fertility in the Jhikhu Khola, Watershed, Nepal.

Norris, A.C. A comparisons of logging residues for the mid-coast of British Columbia; 1981 compared to 1985 . 
Poon, A. An investigation of the water permeance of five chemical sealants.

Simcoe, A. An evaluation of bobcat fellerbunchers in B.C.'s northern interior.

Sirkia, H. Corporate decision making for timber supply and silviculture in British Columbia.

White, D.E. Taxation of small private forests in British Columbia.

Whitwell, D.J. An evaluation of line skidding to centralized landings in the southern interior of British Columbia.

Wriglesworth, B. The use of geosynthetics in forest road construction.

Zanotto, A. Evaluation of some methods used to rehabilitate NSR valley bottom sites in the northern drier maritime subzone of the coastal western hemlock biogeoclimatic zone

Zuccaro, M. Bar coding and on-line tallying in the lumber industry - A new approach to inventory management. (Confidential: cannot be found in the Library)

\section{Forest Sciences Department}

Dr. Gordon Weetman has recently completed a study for the BC Ministry of Forests on the alternatives to clear cutting on the ESSF, SBS, and ICH biogeoclimatic zone old growth forests near Smithers, B.C. In the fall of this year Dr. Weetman will begin a study leave in Sweden, Holland and the United Kingdom.

Dr. John Worrall will be taking a 12-month sabbatical leave commencing September 1 . 1990. During his leave he will be writing a book (co-authored with $\mathrm{Dr}$. Karel Klinda) on dendrology-silvics.

Dr. Hamish Kimmins has recently returned from sabbatical leave.

Dr. Tom Northcote will return from sabbatical leave on September 1.

Dr Harold Weger, a post-doctoral fellow working with Dr. Rob Guy on respiratory patterns in coniferous roots, was recently awarded the Governor General's Gold Medal for the best graduate thesis from Queen's University

\section{Harvesting and Wood Science Department}

The Harvesting and Wood Science Department is pleased to formally announce the approval of a new Industrial Research Chair in Forest Products Biotechnology funded jointly by NSERC, MacMillan Bloedel, Novo Nordisk A/S, Pulp and Paper Institute of Canada and Weyerhaeuser Canada. The tota
NSERC, university and industrial contributions to the program will be $\$ 2.2$ million over 5 years.

Dr. Jack Saddler and Dr. Collette Breuil, the chairholders have now both accepted positions in the Department. They will be located in the Paprican Building in the south campus Discovery Park until the completion of the new Forest Sciences Centre.

Dr. Saddler received his Ph.D. from the University of Glasgow, Department of Microbiology in 1978. Since graduating he has held positions as a temporary lecturer at the University of Glasgow, a Research Associate at the National Research Council (Ottawa) and since 1979 he has led the Biotechnology Department of Forintek Canada Corp (Ottawa). Dr. Saddler will hold an endowed chair in Forest Products Technology.

Dr. Breuil received her Ph.D. in 1977 at the University of Sciences of Lyon, France. Dr. Breuil held positions as a Research Associate at N.R.C. (Ottawa), Professor, Department of Biology, University of Oran, Algeria and most recently Senior Scientist and Group Leader in the Biotechnology Department, Forintek Canada Corp.

Dr. Breuil and Dr. Saddler will be taking up their appointments September, 1990.

Susan B. Watts. Ph.D.

\section{Upcoming Meetings/Réunions à venir}

\section{Global and Environmental Monitoring Techniques and Impacts}

The International Society for Photogrammetry and Remote Sensing is sponsoring a symposium on the topic above at the Victoria Conference Centre, Victoria, B.C., on September $17-21,1990$.

The main topics will be: Interpretation of photographic and remote sensing data, Physical measurements and signatures in remote sensing. Spatial information extraction and manipulation, Renewable resources in rural areas, Non-renewable resources, Water and atmospheric remote sensing, Human settlements, Expert systems for remote sensing, and Global monitoring. The symposium will include presentations, exhibits, workshops, tours, poster sessions, and tutorials.

Contact: ISPRS Symposium 1990, $\%$ Ferihil Technologies Ltd., 702-1483 Douglas St., Victoria, B.C. V8W 3K4. Fax (604) 383-4705.

\section{The Way Ahead}

The 1990 Forest Sector Conference will be held at the Vancouver Trade and Conference Centre, BC Place, Vancouver on September
$26-28,1990$. It is being organized by the Council of Forest Industries of British Columbia with support from Forestry Canada and the BC Ministry of Forests.

The meeting will be a forum for: (1) demonstrating the forest industry's commitment to sustainable development, (2) communicating about major forest issues to a wide audience. (3) analyzing the major challenges facing the forest sector, (4) exchanging expert technical views on new industry technologies, and (5) networking between technical experts and industry managers.

The sessions will be organized under the umbrella of four themes: integrated forest management, manufacturing, trade and marketing, and public affairs.

Two conference companion events will take place. On September 27-28, the trade show Exfor-West organized by the Technical Section of the Canadian Pulp and Paper Association will be held in the BC Place Stadium. On the same dates, wood Expo 90, the largest forest industry trade show in Canada, will also be held in the Stadium More than 500 exhibitions will be on site at the two trade shows.

For more information, contact: 1990 Forest Sector Conference, 720-845 Cambie St., Vancouver, B.C. V6B 4Z9. Tel: (604) 688-0188/9. Fax (604) 688-1573.

\section{BIOFOR/BIOQUAL '90}

The annual BIOFOR/BIOQUAL meeting will be held at the Hugh John Flemming Forestry Centre in Fredericton New Brunswick, on October 29-November 2, 1990. The topic of the meeting will be "The Forest Industry and Environmental Quality."

The BIOFOR Network is concerned with the application of biotechnology in forestry and the forest products industry, while the BIOQUAL Network focuses on the industrial use of biotechnology for the preservation and enhancement of environmental quality.

All sessions will be plenary and will address the following topics:

- tree genetics and wood quality

- microbial-induced corrosion, slimicides, etc., in the pulp and paper industry

- biocontrol of forest pests

- pulp and paper effluent treatment

- biotechnology and effluent regulations

- biomonitoring pulp and paper effluent toxicity

- bioremediation of forest industry sites

- soil and ground water protection.

For further information contact: $\mathrm{Dr}$. T. Sterner, Forestry Canada, Hugh John Flemming Forestry Centre, P.O. Box 4000, Fredericton, N.B., E3B 5P7. Fax (906) 452-3140. 